\title{
PROGRAMOWE ZAŁOŻENIA UNIWERSYTECKIEGO NAUCZANIA W JAGIELLONSKIEJ ODNOWIE KRAKOWSKIEGO STUDIUM GENERALE
}

O losach środkowoeuropejskich państw zadecydowało przyjęcie chrztu w obrządku rzymskim. Czechy uczyniły to już w r. 929 za panowania Wacława I. Mieszko I wraz ze swoimi podwładnymi zdecydował się na ten krok dopiero w roku 966. Węgrzy bez swego władcy Gejzy stali się członkami Kościoła rzymskokatolickiego w 972 roku ${ }^{1}$. W ówczesnych czasach akt chrztu nie ograniczał się bynajmniej do akceptacji zasad wiary chrześcijańskiej. W przypadku wymienionych państw była to także gwarancja samodzielnego bytu politycznego. W miarę zaś rozszerzania się chrześcijaństwa i rosnącej stabilizacji państwowej nastąpiło też stopniowe wchodzenie w orbitę wpływów zachodniej kultury łacińskiej. Dysproporcje były jednak bardzo wielkie. Wobec tego cały proces przebiegał niezwykle powoli, zwłaszcza w położonej na krańcach łacińskiego świata Polsce. Tymczasem już w XII i XIII wieku głównie w Italii i we Francji zwiększyła się liczba szkół partykularnych ubiegających się o status studium generalnego, czyli uczelni nauki uniwersyteckiej.

\section{PIERWSZE WSZECHNICE SRODKOWOEUROPEJSKIE}

Z zamiarem przekształcenia istniejącego przy kościele katedralnym studium particulare w studium generale nosił się już król czeski Wacław II Przemyślida. Wychowany na dworze paryskim i wszechstronnie wykształcony Karol IV Luksemburczyk zdawał sobie jeszcze bardziej sprawę z doniosłej roli nauki w podniesieniu życia kulturalnego społeczeństwa. Jako byłemu uczniowi i podopiecznemu papieża Klemensa VI po jego zatwierdzeniu 26 stycznia 1347 roku udało mu się ten zamiar w pełni

\footnotetext{
* $\mathrm{W}$ przypisach zastosowano następujące skróty:

BJ - Biblioteka Jagiellońska w Krakowie.

Dzieje UJ - Dzieje Uniwersytetu Jagiellońskiego w latach 1364-1764, praca zbiorowa pod red. K. L e p s z e g o, t. 1, Kraków 1964.

KodUJ - Codex diplomaticus Universitatis Studii Generalis Cracoviensis [...] Pars I, ed. Z. P a u i, Cracoviae 1870.
}

1 A. Vetulani, Początki najstarszych wszechnic środkowoeuropejskich, Wrockaw 1970 , s. 89. 
zrealizować już 7 kwietnia 1348 roku. Niewątpliwym sukcesem Karola Luksemburczyka było uzyskanie zgody na naukę teologii. Mimo osobistego wkładu najpotężniejszego władcy ówczesnej Europy, poparcia papieskiego i przychylnego stanowiska duchowieństwa metropolii czeskiej upłynęło sporo czasu, zanim wytworzyły się ostateczne formy organizacyjne i zanim doszło do regularnego nauczania uniwersyteckiego ${ }^{2}$.

Przykład Czech nie mógł ujść uwagi władców sąsiednich państw. W stosunku do króla Czech i cesarza rzymskiego położenie ich było o wiele trudniejsze. Własnych ośrodków nauki uniwersyteckiej zapragnęli bowiem królowie: Kazimierz Wielki i Ludwik I Andegaweński oraz arcyksiążę austriacki Rudolf IV Habsburg, chcąc w ten sposób uniezależnić się od czeskiej ekspansji tak kulturalnej jak i politycznej. W wyniku ich usilnych starań papież Urban V zgodził się na złożenie studiów generalnych najpierw $\mathrm{w}$ Krakowie, potem $\mathrm{w}$ Wiedniu i w starym, bogatym mieście Pécs, czyli w Pięciu Kościołach, bo Buda stała się stolicą królewską dopiero w XV wieku. Zgoda papieska pozwalała na uruchomienie trzech wydziałów, tj. prawa, medycyny i umiejętności wyzwolonych wraz z filozofią. Trudno powiedzieć, $\mathrm{z}$ jakich powodów nie powstały $\mathrm{w}$ tych trzech miastach pełnowydziałowe uczelnie uniwersyteckie, zorganizowane na wzór Studium Generale w Paryżu. Pod tym względem praskie Studium Generale od samego początku górowało nad trzema młodszymi studiami generalnymi w Europie środkowej.

Kazimierz Wielki wystawił uroczysty akt fundacyjny Studium Generale w Krakowie 12 maja 1364 roku. Arcyksiążę austriacki Rudolf IV wydał podobny dyplom erekcji wiedeńskiego Studium Generalnego 12 marca 1365 roku. Pod takimi samymi datami ukazały się też uniwersyteckie akty fundacyjne rajców miast Krakowa i Wiednia. Nie jest natomiast znana ani data, ani treść węgierskiego aktu fundacyjnego Studium Generale w Pécs. Znane natomiast są papieskie bulle konfirmacyjne dla kadłubowych uniwersytetów w Krakowie (1 IX 1364), w Wiedniu (18 VI 1365) i w Pécs (1 IX 1367) wyłączające nauczanie teologii na poziomie wyższym, chociaż mniej więcej w tym samym czasie Innocenty VI dał zezwolenie na erekcję wydziału teologii w Bolonii w roku 1360, a Urban $\mathrm{V}$ pozwolił na utworzenie takiego fakultetu w Padwie $\mathrm{w}$ roku $1363^{8}$. Mimo że w krajach położonych na północ od Alp i na wschód od Renu powstały w krótkim czasie trzy dalsze wszechnice, to jednak istniejące w stolicy króla Czech i Niemiec, cesarza rzymskiego Karola IV Studium Generale, dzięki swemu Wydziałowi Teologii, górowało na tym obszarze.

2 Tamże, s. 66-67.

3 Tamże, s. 95; A. Partyka, Papieskie zatwierdzenia fundacji uniwersytetów srodkowoeuropejs,kich w latach 1347-1386, "Analecta Cracoviensia" 9 (1977) s. 10. 
O ile król Ludwik I i arcyksiążę Rudolf IV przy organizowaniu studiów generalnych posiadali pełne poparcie ze strony władz kościelnych, o tyle wielkiemu Piastowi przyszło działać w zupełnej izolacji ze strony ordynariusza krakowskiego Bodzanty. Wzajemne niechęci pogłębiły się jeszcze bardziej, gdy biskup Bodzanta wbrew woli królewskiej, a za zgodą kurii, został kanclerzem krakowskiego Studium Generale, mając przy tym prawo nadawania licencjatu nauczania (licentia docendi). W związku z tym Kazimierz Wielki zwlekał z faktycznym uruchomieniem założonego przez siebie Studium Generale aż do śmierci biskupa Bodzanty, która nastąpiła z końcem 1366 roku. Zaczęło ono działać dopiero w 1367 roku, gdy nominację na ordynariusza diecezji krakowskiej od Urbana VI uzyskał kandydat królewski, Florian Mokrski ${ }^{4}$.

\section{PROGRAM KAZIMIERZOWSKIEJ FUNDACJI UNIWERSYTETU KRAKOWSKIEGO}

Historia nie przekazała potomności żadnych wiarogodnych szczegółów o faktycznej działalności dydaktycznej założonego przez ostatniego króla Piasta Studium Generale w Krakowie. Chcąc przynajmniej w jakiś sposób poznać przyświecające mu przy tym wielkim akcie idee, trzeba zanalizować wydany przez niego przywilej erekcyjny z dnia 12 maja 1364 roku. Wyrażał on kulturalne potrzeby państwa polskiego XIV wieku. W tym bowiem stuleciu do nauki coraz częściej garnęła się nie tylko młodzież rycerska, lecz także miejska, a w niektórych przypadkach nawet i chłopska. W następstwie tego coraz liczniejsze stały się wyjazdy Polaków na zagraniczne studia uniwersyteckie. Dzięki temu z roku na rok powiększało się nieliczne jeszcze grono ludzi z wyższym wykształceniem. W okresie panowania Kazimierza Wielkiego ich liczba w Polsce sięgała ponad sześćdziesiąt osób ${ }^{5}$. Monarcha polski i jego doradcy zdawali sobie doskonale sprawę $\mathrm{z}$ tego, że liczbę ludzi wykształconych można by znacznie powiększyć przez założenie wyższej uczelni w kraju. Jej należyte funkcjonowanie pozwoliłoby podnieść poziom kultury rodzimej i zapewnić administracji państwowej dopływ odpowiednich urzędników. Własne studium generale uniezależniłoby kulturę rodzinną od wpływów obcych. zwłaszcza od cesarskiego ogniska nauki uniwersyteckiej w Pradze.

Występujące w Kazimierzowskim akcie erekcyjnym wyrażenia, ażeby założony w Krakowie uniwersytet stał się perłą kwitnących nauk, aby w nim rozwijały się wszystkie dozwolone dziedziny wiedzy, by w nim rodziły się nowe daktryny $\mathrm{i}$ by $\mathrm{z}$ niego wychodzili znakomici doradcy, ludzie cnotliwi i wykształceni w różnych umiejętnościach - pozwalają

A. Vetulani, jw., s. 184.

s. Dąbrowski, Czasy Kazimierza Wielkiego, [w:] Dzieje UJ, s. 21. 
wnioskować, że pierwszemu fundatorowi Uniwersytetu Krakowskiego chochodziło o czterowydziałowe studium generale wraz $\mathrm{z}$ wydziałem teologii i o podniesienie moralnego i naukowego poziomu w całym kraju:

„Postanowiliśmy w mieście naszem Krakowie wyznaczyć, obrać, ustanowić i urządzić miejsce, na któremby szkoła powszechna w każdym dozwolonym wydziale kwitnęła, a dla przyszłości na wieczne czasy tem pismem jej istnienie zapewnić chcemy. Niechże więc tam będzie nauk przemożnych perła, aby wydawała męże dojrzałością rady znakomite, ozdobą cnót świetne i w różnych umiejętnościach biegłe; niechaj otworzy się orzeźwiające źródło, a z jego pełności miech czerpią wszyscy naukami napoić się pragnący" ".

Założenie w Krakowie Studium Generalne przez podniesienie poziomu umysłowego miało przyczynić się też do wyrównania dysproporcji, jakie na tym odcinku zachodziły między Polską a niektórymi państwami zachodniej i poludniowej Europy. Funkcjonujący w kraju uniwersytet dałby także możność kształcenia się szerszym rzeszom młodzieży polskiej, zwłaszcza pochodzącej z mniej zamożnych warstw społecznych. Studia uniwersyteckie stały się również dogodną okazją, jeżeli można to wyrazić językiem współczesnym, do awansu społecznego. Kultura miała też stać się dodatkowym czynnikiem scalającym cały naród, który dotkliwie odczuł niedawne rozbicie dzielnicowe Polski.

Plan erygowania trzech katedr prawa kanonicznego i aż pięciu katedr prawa rzymskiego, ze stosunkowo wysokim uposażeniem, stanowi dobitne świadectwo, że Kazimierzowi Wielkiemu chodziło głównie o wykształcenie jak największej liczby prawników dla administracji tak państwowej jak i kościelnej. Różnice te stają się jeszcze jaskrawsze, jeżeli się zważy fakt, że poza ośmiu projektowanymi katedrami prawa kanonicznego i rzymskiego ufundowano dwie katedry medycyny i tylko jedną katedrę przeznaczoną na wykłady umiejętności wyzwolonych. Do tego doszły jeszcze wielkie różnice w uposażeniu?. Powołanie tylko jednego mistrza do wykładów nauk wyzwolonych przy o połowę niższym wynagrodzeniu wskazuje na to, że oparte pod względem organizacyjnym na pierwotnym wzorze organizacyjnym uczelni bolońskiej, padewskiej i neapolitańskiej Studium Generale Cracoviense nie miało stać się uczelnią, która by jak największej liczbie osób zapewniła wyższe wykształcenie ogólne. Przy założeniu, że tylko jeden mistrz miał wykładać wszystkie dyscypliny wyzwolone i filozoficzne, nie mogło być mowy o szerszym

${ }^{B}$ Kazimierza Wielkiego Dyplom założenia Uniwersytetu z 12 maja 1364 r., w tłumaczeniu polskim S. Krzyżanowskiego: zob. tegoż, Poselstwo Kazimierza Wielkiego do Awinionu $i$ pierwsze uniwersyteckie przywileje, Kraków 1900, s 89.

7 KodUJ 1 s. 3. 
ich nauczaniu. Kazimierz Wielki w swoich ambitnych planach politycznych, których realizację miał ułatwić mu założony uniwersytet w Krakowie, dążył do wzmocnienia swojej władzy nad rozległymi terytoriami wchodzącymi w skład zjednoczonej Polski przez zupełną centralizację i do stworzenia sprawnie funkcjonującego aparatu administracyjnego państwa, w skład którego wchodziliby nie tylko wykształceni prawnicy, lecz także znakomici doradcy. Według intencji fundatora, Studium Generale w stolicy Polski miało więc spełniać zadania pragmatyczne. Przedwczesna śmierć króla w roku 1370 przerwała także działalność zaledwie od roku 1367 funkcjonującego Uniwersytetu Krakowskiego. Uczelnia ta została wprawdzie odnowiona $\mathrm{z}$ biegiem czasu, ale Kazimierzowskie ideały, jakim ona miała służyć, nie odżyły w zupełności.

\section{ZMIANA PROGRAMU PRZY ZABIEGACH O ODNOWE WSZECHNICY KRAKOWSKIEJ}

Stosunkowo dosyć długi okres przygotowawczy poprzedził odnowę podupadłego Uniwersytetu Krakowskiego. Z mów wygłoszonych przez Bartłomieja z Jasła wynika, że zabiegano o to w Krakowie przynajmniej od roku $1390^{8}$. Podobnie jak w programie Kazimierzowskiej fundacji, tak i przy pierwszych próbach restauracji krakowskiej uczelni uniwersyteckiej preferowano nadal studia prawnicze. Prawa uczyło, jak wynika z relacji Bartłomieja z Jasła, aż dwóch profesorów, podczas gdy obowiązek wykładania dyscyplin wyzwolonych i filozoficznych spoczywał tylko na jednym mistrzu. Należy jednak podkreślić, że w nastawieniu do potrzeby nauczania filozofii zaszła poważna zmiana. O ile wydany w roku 1364 dyplom nie wspominał w ogóle o nauczaniu filozofii, o tyle w roku 1390 Bartłomiej z Jasła wymienił tę naukę, a nawet wypowiedział pod jej adresem słowa pochwalne. Co więcej, mówca zdawał sobie doskonale sprawę z tego, że filozofia była przez wiele lat skazana na banicję i że broniono jej wstępu do Krakowa. Wyrażał się o niej jako o pani, a więc uważał ją za naukę naczelną ,rządzącą” innymi naukami, zwłaszcza zaś umiejętnościami wyzwolonymi ${ }^{\ominus}$. Zwracając się do studentów, zachęcał ich

${ }_{8}^{8}$ M. Kowalczyk, Bartłomiej z Jasta a próba odnowienia Uniwersytetu Krakowskiego, [w:] Sprawozdania $z$ posiedzeń Komisji Oddziału PAN w Krakowie, Kraków 1973, s. 130-134; taż, Odnowienie Uniwersytetu Krakowskiego w świetle mów Bartłomieja z Jasta, „Małopolskie Studia Historyczne” 6 (1964) s. 23-42; Z. Kozłowska-Budkowa, Odnowienie Jagiellońskie Uniwersytetu Krakowskiego (1390-1414), [w:] Dzieje UJ, s. 37 n.; J. R e beta, Komentarz Pawza $z$ Worczyna do „Etyki nikomachejskiej” Arystotelesa z 1424 roku. Zarys problematyki filozoficzno-społecznej, Wrocław 1970, s. $17 \mathrm{n}$.

9 ,Regimen domine imperiose auctoritatis, videlicet domine philosophie [...] hic tamen noviter incepit vigorari, scilicet tunc, cum possessio ipsius ei hic restituebatur per Studii instauracionem, que prius et ablata fuerat et a qua per plures annos fuerat proscripta sive enormiter propulsata" (BJ rkps 2192, k. 36; por. M. K o w a l- 
gorąco do solidnej nauki. W tych ogólnych wzmiankach trudno dopatrzyć się określonych założeń przyszłego nauczania uniwersyteckiego. Są one wszakże dobitnym świadectwem tego, że uczeni $\mathrm{z}$ okresu panowania królowej Jadwigi i króla Władysława Jagiełły, którzy około 1390 roku próbowali odnowić podupadłą uniwersytecką uczelnię krakowską, nie obniżali wartości nauczania filozofii kosztem nauk prawniczych.

Bartłomiej z Jasła nie sprecyzował bliżej, o jaką filozofię mu chodziło. $\mathrm{Z}$ jego lapidarnej wzmianki wynika jednak, że miała to być mądrość nie tylko konieczna dla zbawienia duszy, do czego ograniczało ją wielu myślicieli średniowiecznych pozostających zwłaszcza pod większym wpływem platonizmu, augustynizmu czy też nowego stylu pobożności - devotio moderna, lecz także niezbędna do zaspokojenia doczesnych, cielesnych potrzeb człowieka ${ }^{10}$. Nauczana mądrość miała służyć tym potrzebom, słowem - miała obejmować całego człowieka, jak to akcentowali średniowieczni i renesansowi humaniści. Tego rodzaju mądrość nie mogła ograniczać się ani do metafizyki, ani do etyki, ale musiała także uwzględniać medycynę, a przede wszystkim umiejętności rzemieślnicze, służące wytwarzaniu dóbr doczesnych. W wypowiedziach Bartłomieja z Jasła pojawiły się inne idee pragmatyczne. Różniły się one w sposób zasadniczy od „,politycznego pragmatyzmu" reprezentowanego przez króla Kazimierza Wielkiego.

Wygłoszone przez Barłłomieja z Jasła mowy wyrażały nie tylko jego stanowisko, lecz także zapatrywania pozostałych twórców nowego programu uniwersyteckiego nauczania w Krakowie. Mimo że w dalszym ciągu wyznaczano stosunkowo dosyć dużo miejsca na naukę prawa, to jednak wskazanie na ważność studium filozofii stanowi widomy znak powolnych przemian, jakie w ostatniej dekadzie XIV w. wprowadzili do założeń programowych uniwersyteckiego nauczania reorganizatorzy Wszechnicy Krakowskiej. Uwzględnienie w programie naukowym w większym stopniu filozofii, a przy tym i nauk wyzwolonych, wskazuje na to, że większą wagę zaczęto przywiązywać do ogólnego wykształcenia uniwersyteckiego niż do fachowych studiów prawniczych.

\section{JAGIELLOŃSKA EREKCJA WYDZIAEU TEOLOGII W KRAKOWIE}

Podjęta około 1390 roku próba odnowy podupadłego Uniwersytetu Krakowskiego przyniosła pożądane rezultaty dopiero po kilku latach.

c zy k, Odnowienie Uniwersytetu Krakowskiego w swietle mów Bartłomieja $z$ Jasta, jw., s. 34, przypis 41).

10, Ex istis volens considerare perpendere posset, quantum domum seu beneficium sit Studium, in quo traditur et aquiratur sapiencia, non solum que ald salutem anime est necessaria, ut ex predictis et multis aliis ostendi posset, sed eciam traditur in ipso sapiencia pro utilitate corporis temporali" (BJ rkps 2192, k. $115 \mathrm{v}$; por. M. K ow a l c z k , jw., s. 35, przypis 46). 
Mimo że czynniki zarówno państwowe, jak i kościelne zdawały sobie sprawę $\mathrm{z}$ potrzeby takiej uczelni w stolicy państwa polskiego, jej restauracja toczyła się dosyć powoli. Spośród głównych przyczyn, które nie pozwalały na jej szybszy przebieg, należy wymienić nieła.twą sytuację polityczną państwa polsko-litewskiego, brak dostatecznych środków finansowych i odpowiedniej rodzimej kadry naukowej. Mimo to nie zaniechano starań o utworzenie pełnego uniwersytetu, za jaki według ówczesnych przekonań mogło uchodzić tylko studium generale posiadające cztery fakultety: teologii, prawa, medycyny i umiejętności wyzwolonych. Uzyskanie przez odnowicieli i organizatorów podupadłego Uniwersytetu Krakowskiego od stolicy apostolskiej w dniu 11 stycznia 1397 roku zgody na utworzenie wydziału teologii, którego nie posiadała Wszechnica Kazimierzowska, należy uznać za wielki sukces króla Władysława Jagiełły, a przede wszystkim jego małżanki Jadwigi, królowej Polski:

„Bonifacy biskup, sługa sług Bożych. Na wieczną rzeczy pamiątkę. NIEZWYKŁEGO PRZYWIĄZANIA UCZUCIE, jakie najdroższy w Chrystusie syn nasz Władysław król i najdroższa w Chrystusie córka nasza Jadwiga, królowa Polski, najjaśniejsi, okazują nam i Kościołowi Rzymskiemu, zasługuje na to, abyśmy się przychylnie odnieśli do ich życzeń, a zwłaszcza do tych, przez które rozszerza się cześć imienia Bożego i wiary katolickiej, utrzymuje się sprawiedliwość, z korzyścią toczą się sprawy państwowe i prywatne, pomnaża się wszelka ludzka pomyślność" ${ }^{11}$.

Z przytoczonego tekstu bulli Bonifacego IX wynika, że powołany do życia w Krakowie Wydział Teologii miał spełniać cztery główne zadania. W pierwszym z nich chodziło o ożywienie życia religijnego w kraju i o podniesienie poziomu wykształcenia teologicznego kleru polskiego. Być może, że z utworzeniem Wydziału Teologii w stolicy Polski wiązano jakieś nadzieje pełnej chrystianizacji rozległych połaci państwa litewsko-ruskiego, ale $\mathrm{w}$ bulli papieskiej nie powiedziano tego expressis verbis. Kazimierz Wielki mógł mówić tylko o podniesieniu moralności w kraju. Tymczasem Władysław Jagiełło i Jadwiga posiadali jeszcze ważki argument szerzenia wiary na należących do nich rozległych ziemiach litewsko-ruskich, które były po części pogańskie, po części schizmatyckie. Argument chrystianizacji przyniósł im pełny sukces dyplomatyczny. Ale przepełnionej ideałami królowej Jadwidze nie chodziło bynajmniej tylko o taki sukces. Jej życiową ideą przewodnią było bowiem żarliwe pragnienie faktycznego nawrócenia ludności Wielkiego Księstwa Litewskiego. Misji religijnej miało towarzyszyć powolne podnoszenie poziomu życia kulturalnego na tych ziemiach. Królowa Jadwiga zdawała zapewne sobie sprawę z tego, że erygowany w Krakowie Wydział Teologii bez dłuższej

${ }^{11}$ Bulla papieża Bonifacego IX erygujaca Wydziat Teologiczny na Uniwersytecie Krakowskim, „Analecta Cracoviensia” 9 (1977) s. 8. 
tradycji teologicznej $\mathrm{w}$ tym mieście, a zwłaszcza bez odpowiedniej kadry profesorów teologii nie będzie mógł przez dłuższy okres czasu wywiązać się z tego zadania. Przyszłość bowiem pokazała, że te przeczucia młodej królowej były słuszne. Jeszcze w latach dwudziestych XV wieku Andrzej z Kokorzyna, profesor teologii i archidiakon krakowski, skarżył się na niski poziom umysłowy kleru w wizytowanej przez niego diecezji krakowskiej ${ }^{12}$. Przy końcu XIV wieku nie było chyba lepiej. Przy takim stanie wykształcenia kleru nie można go było angażować do zadań misyjnych. Za panowania dynastii Jagiellonów krakowski Wydział Teologii wypromował wprawdzie pokaźną liczbę bakałarzy i doktorów teologii ${ }^{18}$, którzy właśnie królowę Jadwigę z najwyższą rewerencją wspominali jako fundatorkę i dobrodziejkę ich fakultetu, ale brak danych źródłowych, żeby się oni kwapili do ugruntowania chrześcijaństwa na Litwie i Rusi. Stąd też Jadwiga, niezależnie od fundacji Wydziału Teologii w Krakowie, starała się jednocześnie o założenie i dobre wyposażenie specjalnej bursy dla litewskich studentów teologii, aby ci po otrzymaniu dobrego wykształcenia i odpowiedniego przygotowania lepiej sprostali trudnym zadaniom misyjnym $\mathrm{w}$ swoim rodzinnym kraju ${ }^{14}$. Te wszystkie zabiegi królowej Jadwigi chroniły ludność Wielkiego Księstwa Litewskiego przed nawracaniem mieczem ze strony Krzyżaków. Unia Polski z Litwą, jak i rozwiązanie we własnym zakresie sprawy całkowitego nawrócenia ludności litewskiej i ruskiej położyły bowiem tamę ekspansji krzyżackiej na Wschód.

Pozostałe trzy zadania, jakie Bonifacy IX w swej bulli stawiał krakowskiemu Wydziałowi Teologii, miały na celu też dobro człowieka. Fakultet miał przede wszystkim stać na straży utrzymania sprawiedliwości społecznej, czuwać nad korzystnym przebiegiem spraw państwowych i prywatnych i wreszcie mieć na uwadze pomyślny rozwój samego człowieka. Trzeba przy tym podkreślić, że zaakcentowano tutaj najważniejsze zasady etyki społecznej, państwowej i indywidualnej. Stanowią one trzon etyki tak arystotelesowskiej, jak i chrześcijańskiej. Ich podanie w bulli papieskiej jako dewizy działalności dla nowo kreowanego Wydziału Teologii ma też swoją głębszą wymowę. Wiązało się to z praktycyzmem filozofii nowej szkoły. Było wykładnikiem głębokich przemian zachodzących w koncepcji teologii. Było antycypowaniem idei piętnastowiecznego humanizmu renesansowego, głoszącego potrzebę równomiernego rozwoju całego człowieka w jego uwarunkowaniach doczesnych. Wy-

12 M. Markowski, Poglady filozoficzne Andrzeja $z$ Kokorzyna, ,Studia Mediewistyczne" 6 (1964) s. 73-74.

13 Tenże, Spis osób dopuszczonych do wykładów $i$ do katedry na Wydziale Teologii Uniwersytetu Krakowskiego $w$ XV w., [w:] Materiaty i studia Zakładu Historii Filozofii Starożytnej i Sredniowiecznej, t. 4, Wrocław 1965, s. 167-174.

$14 \mathrm{Z}$. Kozłowska-Budk owa, jw., s. $40-41$. 
dział Teologii w Krakowie, którego powstanie było pomyślnym uwieńczeniem najgorętszych pragnień młodej królowej Polski Jadwigi i owocem starań nie tylko jej, lecz także jej małżonka króla Władysława Jagiełły i jej doradcy biskupa krakowskiego Piotra Wysza - mial nie tylko służyć określonym aktualnym potrzebom ogromnego państwa polsko-litewskiego, lecz także spełniać uniwersalne i ponadczasowe cele, koncentrujące się na samym człowieku, żyjącym pomyślnie i szczęśliwie w sprawiedliwych stosunkach międzyludzkich i w państwie gwarantującym korzystny rozwój interesów społecznych i prywatnych swoich obywateli.

\section{JAGIELLOŃSKA ODNOWA UNIWERSYTETU KRAKOWSKIEGO}

W roku 1397, gdy w Krakowie uzyskano zgodę papieską na erygowanie Wydziału Teologii, nie doszło jeszcze do oficjalnego otwarcia czterowydziałowego uniwersytetu. Sytuacja była w tym czasie o wiele korzystniejsza niż wtedy, gdy trzywydziałowe studium generalne zakładał Kazimierz Wielki. Przy jagiellońskiej odnowie Wszechnicy Krakowskiej biskup krakowski z klerem miejscowym jak najściślej współpracował z parą królewską. Być może, że mimo hojności królowej Jadwigi warunki materialne na faktyczne otwarcie czterowydziałowej uczelni wyższej były jeszcze wciąż niewystarczające, że brak było odpowiednich lokali do zajęć dydaktycznych czy na mieszkania dla profesorów i dla studentów. Nie ulega natomiast wątpliwości, że otwarcie pełnego Studium Generale wstrzymywał brak odpowiedniej kadry naukowej. Nie chciano jej ściągać z odległych państw. Czekano zapewne na ukończenie studiów przez polskich studentów przebywających w Pradze. Plan powierzenia zajęć uniwersyteckich w Krakowie rodzimym wykładowcom i profesorom był mądrym posunięciem ze strony odnowicieli i organizatorów Uniwersytetu Krakowskiego. Uniezależniał on bowiem tę uczelnię od różnego rodzaju wpływów obcych i umożliwiał swobodne wytyczenie programu przyszłego nauczania uniwersyteckiego.

Królowej Jadwidze nie było dane doczekać uroczystej chwili ponownego oficjalnego otwarcia Uniwersytetu Krakowskiego. Jej zapis testamentowy jednak ten moment przybliżył, a może go wręcz umożliwił. Pozostawione bowiem przez nią dobra materialne pozwoliły na przyobleczenie żywionej przez nią idei w realny kształt i stały się zaczynem, z którego wyrósł odnowiony Uniwersytet Krakowski, by za panowania dynastii Jagiellonów przeżyć złoty okres swego rozwoju.

Oficjalne otwarcie czterowydziałowego Studium Generale w Krakowie nastąpiło po wyznaczeniu w dniu 22 lipca 1400 roku przez króla 
Władysława Jagiełłę pierwszego domu uniwersyteckiego przy ulicy św. Anny, zwanego najpierw Kolegium Królewskim lub Kolegium Artystów, a od roku 1449 Kolegium Większym:

„Aby zaś doktorowie, mistrze, licencyaci, bakałarze i studenci rzeczonego uniwersytetu krakowskiego, swoje wykłady, ćwiczenia i czynności naukowe swobodniej i wygodniej mogli i zdołali odbywać, na mieszkanie mistrzów, i na codzienne i powszechne zbieranie się studentów i scholarów dom nasz [...] postanowiliśmy wyznaczyć [...]; a dom ten uniwersytetowi rzeczonemu oddajemy na własność, do niego wcielamy i przyłączamy na zawsze i na wieki, nic w nim prawa i dziedzictwa sobie i następcom naszym nie zastrzegając" 15 .

Akt ten stworzył warunki do wydania przywileju fundacyjnego i do oficjalnego otwarcia roku akademickiego, co nastąpiło niebawem. Prawną podstawę istnienia odnowionego Uniwersytetu Krakowskiego stanowi wydany w dniu 26 lipca 1400 roku przywilej fundacyjny Władysława Jagiełły. Chociaż oficjalnie był on teraz głównym odnowicielem Uniwersytetu Krakowskiego, to jednak uczelnia ta nie miała już służyć w takim stopniu interesom władzy królewskiej, jak to było w koncepcji króla Kazimierza Wielkiego; według niego bowiem uniwersytet miał dodatkowo umocnić i ugruntować władzę królewską. Tymczasem możnowładztwu polskiemu, które wyniosło na tron Władysława Jagiełłę, nie zależało wcale na takiej władzy. Odnowione Studium Generale miało wprawdzie spełniać funkcję pragmatyczną, ale została ona $w$ inny sposób pojęta. Stało się to na skutek innej jego koncepcji. W czterowydziałowym Uniwersytecie Krakowskim dominującej roli nie mógł odgrywać Wydział Prawa, ograniczony zresztą głównie do prawa kanonicznego:

„Nie wątpiąc, że to poddanym rzeczonego królestwa i ziem naszych zbawienny pożytek przyniesie [...], postanowilliśmy w mieście naszem Krakowie miejsce, na którymby szkoła powszechna w każdym dozwolonym wydziale kwitnęła, mianowicie w teologii, tj. w piśmie świętym, w prawie kanonicznem i rzymskiem, w fizyce i sztukach wyzwolonych, wyznaczye" ${ }^{16}$.

Ufundowanie Wydziału Teologii w Krakowie było podyktowane nie tylko tymi względami, że w ówczesnych czasach teologia uchodziła za naczelną naukę, lecz także racją ugruntowania chrześcijaństwa na ziemiach litewsko-ruskich, co teraz zaznaczono wyraźnie:

„Ku temu szczególnie, starannie obmyślane zamiary i przedsięwzięcia nasze kierujemy i troskliwie wewnętrzną czujność naszą zwracamy, aby mieszkańców i poddanych ziem naszych litewskich, tych zwłaszcza, którzy

15 St. Krzyżanowski, jw., s. 109-110; por. Kod UJ 1 s. 28.

16 St. Krzyżanowski, jw., s. 106. 
w zastarzałym pozostając błędzie byli naszymi towarzyszami ciemności, a których przyjęciem świętej wiary katolickiej do łona świętej matki Kościoła przywiedliśmy $\mathrm{z}$ woli tego, [...] na synów światła nawrócić z pomocą i współdziałaniem tych, których umysły mądrości i nauki pełność ozdobiła, to jest ludzi $\mathrm{w}$ podstawach i tajnikach pisma biegłych, których radą tron królewski się umacnia, a cnotliwymi czynami rzeczpospolita stale $w$ zdrowie i sily wzrasta" ${ }^{17}$.

Zadanie, które Wydział Teologii Uniwersytetu Krakowskiego miał realizować przez kształcenie rodzimego duchowieństwa i teologów, miało więc w pierwszym rzędzie charakter religijny. Miało ono też wydźwięk polityczny. Istnienie i funkcjonowanie tego fakultetu w Krakowie godziło bowiem także w interersy Krzyżaków, którzy pod pozorem nawracania Litwinów i Rusinów na wiarę chrześcijańską realizowali swoje zaborcze plany. Fakt, że pierwsi krakowscy profesorowie prawa nadali wykładanemu prawu kanonicznemu specyficzne znaczenie, uważając je za najbardziej wszechstronną dyscyplinę, dotyczącą spraw duchowych i świeckich, sprawił, że założony w Krakowie Wydział Prawa Kanonicznego służył też życiu i to zarówno kościelnemu, jak i państwowemu. Wspaniały rozwój prawa narodów już $w$ drugim dziesięcioleciu XV wieku jest najlepszym świadectwem tego, jak profesorowie prawa odnowionego Uniwersytetu Krakowskiego bronili gorliwie interesów państwowych. Z tej racji król Władysław Jagiełło spodziewał się pomocy i rady nie od określonej grupy, lecz od wszystkich profesorów krakowskich. Chociaż odnowiona Wszechnica Krakowska nie podlegała bezpośrednio władzy królewskiej i chociaż przywilej fundacyjny nie wysuwał na pierwszy plan sprawy służby na rzecz państwa, to jednak profesorowie tej uczelni w ciągu XV wieku dostarczyli niemało pięknych przykładów swego żarliwego zaangażowania $\mathrm{w}$ sprawy państwowe.

Przywilej fundacyjny Władysława Jagiełły powtarzał wprawdzie niektóre fragmenty dyplomu fundacyjnego wydanego przez Kazimierza Wielkiego, jeżeli chodzi o program oświaty w społeczeństwie polskim, ale szedł na tym odcinku o wiele dalej. Zakładał on wyraźnie podniesienie poziomu oświaty $\mathrm{w}$ społeczeństwie polskim do takiego stopnia, ażeby nastąpiło zrównanie z innymi krajami: „Dlatego zaiste za zrządzeniem Najwyższej potęgi rozlicznych ziem dostąpiliśmy panowania i królestwa polskiego otrzymaliśmy koronę, abyśmy je blaskiem uczonych osób oświecili, ich naukami jego niedostatki i cienie usunęli, i z innym krajami je zrównali" ${ }^{18}$. Ten ambitny program miała realizować cała społeczność uniwersytecka, ale największe zadania spoczęły na magistrach i bakała-

17 Tamże, s. 105; por. Z. Kozłowska-Budkowa, jw., s. 47; J. Rebeta, jw., s. 21.

18 St. Krzyżanowski, jw., s. 106. 
rzach nauk wyzwolonych. Większość z nich po studiach uniwersyteckich rozchodziła się po całym kraju, obejmując niejednokrotnie stanowiska rektorów lub nauczycieli szkół. Odrestaurowany Uniwersytet Krakowski miał podnosić poziom kultury umysłowej nie tylko w stolicy Polski, lecz także w najodleglejszych jej krainach: „Tejże szkole powszechnej, którąśmy ku ozdobie naszej świętej korony polskiej w rzeczonym mieście Krakowie wskrzesić postanowili, pragnąc usilnie rozwój szczęśliwy zapewnić i oddalonych krain mieszkańców do przebywania do niej zachęcić" ${ }^{19}$. Szerzenie oświaty w społeczeństwie polskim było pomyślane jako jeden z czynników umocnienia kraju.

Odnowiony dzięki uprzednim staraniom i darom królowej Jadwigi przez króla Władysława Jagiełłę Uniwersytet Krakowski spełniał nadal cele polityczne, społeczne i kulturalne. Pierwszy z nich został jednak dosyć zmieniony. Pragmatyzm polityczny, jeżeli wolno się tak wyrazić, miał $\mathrm{w}$ zmienionych warunkach historycznych służyć nie umacnianiu władzy monarszej, lecz ugruntowaniu potęgi państwa polsko-litewskiego, co stało się konieczne w obliczu coraz to bardziej wzrastających uzurpatorskich roszczeń terytorialnych ze strony państwa krzyżackiego.

\section{NAUKOWY PROGRAM MOWY INAUGURACYJNEJ \\ STANISEAWA ZE SKARBIMIERZA}

Lekcją z prawa kanonicznego rozpoczął wykłady na odnowionym Uniwersytecie sam jego kanclerz, biskup krakowski Piotr Wysz z Radolina. Bezpośrednio przed lub po tym wykładzie pierwszy rektor tej uczelni Stanisław ze Skarbimierza wygłosił mowę inauguracyjną, która podawała w ogólnych zarysach założenia programu naukowego odrestaurowanej uniwersyteckiej uczelni krakowskiej. W centrum tego programu znalazł się człowiek. Z tej racji nuta troski o jego dobro i pełny rozwój jego osobowości znalazła wyraz w mowie inauguracyjnej Stanisława ze Skarbimierza. Właśnie pod tym kątem scharakteryzował on dyscypliny mające stanowić przedmiot wykładów uniwersyteckich. Program, który mówca przed swoimi słuchaczami wyłożył, mieli realizować pochodzący z różnych narodowości profesorowie odnowionej uczelni, złączonych miłością bliźniego: „Podnieście oczy a patrzcie na dom, gdzie się zebrali magistrowie różnych narodów, jednym tylko węzłem miłości bliźniego złączeni" ${ }^{19}$. Podkreślenie, że właśnie ta a nie inna cecha stanowi ogniwo łączące krakowską społeczność uniwersytecką, stanowiło - w przekona-

19 Mowę inauguracyjną Stanisława ze Skarbimierza cytuję w przekładzie M. W is zni ew skiego: Historia literatury polskiej t. 4, Kraków 1842, s. 251. Tekst oryginalny mowy $w$ języku lacińskim zachował się w rękopisach BJ: $191 \mathrm{~s} .714$ $721 ; 723$, s. $413-419$. 
niu pierwszego rektora odnowionego Studium Generale - niejako rękojmię gwarancji realizacji nakreślonego planu naukowego.

Stanisław ze Skarbimierza, omawiając założenia programu naukowego odnowionego Uniwersytetu Krakowskiego, podkreślał, że duszą człowieka powinna przede wszystkim zajmować się teologia. Tę zaś, jeżeli idzie o jej miejsce w hierarchii nauk, porównywał do głowy człowieka, a jeżeli zawarta jest w niej także inna problematyka, przynosi najwyższy zaszczyt uczelni: „Teologia zaś [mówi] głównie o duszy [...] Teologia jest na kształt głowy [...] zaszczyt co do teologii, w której się wszystko zawiera, cokolwiek gdzie indziej znajduje się" ${ }^{20}$. Jest rzeczą charakterystyczną, że pierwszy rektor odnowionego Uniwersytetu Krakowskiego poświęcił stosunkowo mało miejsca nowo założonemu Wydziałowi Teologii, jeżeli się zważy, jak ogromną wagę do tego fakultetu przywiązywały inne uniwersytety $\mathrm{w}$ wiekach średnich. $\mathrm{Z}$ mowy jego nie wynika, żeby wiązał funkcję tego wydziału z szerszymi planami politycznymi państwa polsko-litewskiego.

O ile teologia, zdaniem Stanisława ze Skarbimierza, dotyczy głównie spraw duchowych, o tyle prawo kanoniczne ma za przedmiot sprawy duchowe i rzeczy świeckie, a prawo cywilne - głównie te ostatnie: „To są trzy fakulteta wzajemnie się wspierające, a są światłem matki naszej S. Kościoła. Różnią się zaś tem: iż prawo cywilne mówi głównie o rządzie rzeczy świeckich [...], a prawo kanoniczne raz o rzeczach świeckich, drugi raz o duchowych" ${ }^{21}$. W pierwszej mowie inauguracyjnej, wygłoszonej z okazji oficjalnego otwarcia odnowionego Uniwersytetu Krakowskiego, znajduje się dużo pochwal wypowiedzianych pod adresem prawa, zwłaszcza dekretów. To staje się zrozumiałe, jeżeli się zważy, że wygłaszał ją przecież i prawnik, i pierwszy znakomity mówca Studium Generale w Krakowie. Wydaje się jednak, że w roku 1400 były jeszcze żywe, wyrażone w akcie erekcyjnym Kazimierza Wielkiego i w mowie magistra Bartłomieja z Jasła, idee o doniosłej roli prawa w życiu społecznym, politycznym, państwowym i kościelnym. Wielkie znaczenie prawa, zdaniem Stanisława ze Skarbimierza, wynika wszakże głównie z tego, że jest to nauka nie tylko pożyteczna, lecz także najpowszechniejsza. Zajmuje się ona bowiem w pewnym stopniu także tymi sprawami, o których traktują nauki wchodzące w skład trivium, quadrivium, jak również filozofia praktyczna, medycyna i teologia:

„Cudowną jest nauką prawo kanoniczne, a to dla swej głębokości, bo co w Piśmie świętym tu i ówdzie jest rozproszone, to fakultet kanoniczny zagłębiając się jasno wykłada [...] Cudowną jest nauką dla powszechności swej, bo $\mathrm{w}$ niej zawarte są zdania filozofów, słowa świętych pańskich, wyrazy

20 M. Wiszniewski, jw., s. 248, 251.

17 - Analecta Cracoviensia 
poetów, powody prawników, przyczyny artystów, tak iż tu mylnie znajdzie się $\mathrm{w}$ treści wszystko, czego się skądkolwiek dowiedział [...] Cudowna jest ta nauka pożyteczna i chwalebna, bo zawiera w sobie trivium i quadrivium; obejmuje bowiem ortografię, etymologię i prozodyą; używa ekonomiki, która nakłania i zakazuje drugiemu źle czynić, zawiera politykę, która uczy każdemu oddać to co sprawiedliwość nakazuje, uczy geometryi i arytmetyki i wiele innych; uczy astronomii, mówi o pokorze i posłuszeństwie, doświadcza ręki w muzyce, o kleryków obowiązkach, różnymi mamidłami medycynę sobie zadawać każe, o pokucie ì odpuszczeniu i wiele innych" 22.

Prawo kanoniczne dzięki swej ogólnej funkcji i rozległemu przedmiotowi badań przyczynia się najbardziej do wywyższenia człowieka w hierarchii społecznej i do jego doskonałości: „Weź pierwszą z nauk, naukę kanonów, a wywyższy cię i podniesie i doskonałym uczyni" ${ }^{23}$.

Człowiek wartościowy, zdaniem Stanisława ze Skarbimierza, posiada szczególne znaczenie dla społeczeństwa. Z tej racji należy troszczyć się o to, ażeby żył jak najdłużej. Troska o ciało człowieka należy oczywiście do obowiązków lekarzy. Zadaniem zaś uniwersytetu jest ich kształcenie:

„Magistrowie medycyny i nauk wyzwolonych, które dzień i noc zawsze wołają, albowiem medyk troskliwy jest, gdy wyrzuca rzeczy obce, wzmacnia słabe, dostarcza lekarstw serdecznych, gdy odświeża soky żywotne, podaje wzmacniające głowę lekarstwa na głowę, rozweselające na serce, wątrobę i na inne choroby wedle ich rodzaju i stopnia, a jako prawnik musi radzić całej powszechności, aby co ciału społeczeńskiemu nie szkodziło, tak medyk podaje radę ciału materyalnemu, aby społeczeństwo pożytecznego nie postradało członka" 24 .

Lekarze, troszcząc się o zdrowie człowieka, spełniają ważną misję społeczną. Pod wpływem rodzącego się humanizmu ich ranga społeczna stawała się coraz to większa. Tak bardzo z ideałami humanizmu związana troska o całego człowieka, a więc także jego ciało, znalazła swój wyraz już w programie naukowym Uniwersytetu Krakowskiego fundacji Kazimierzowskiej, czego najlepszym dowodem było utworzenie na tej uczelni aż dwóch katedr medycyny. Pod tym względem odnowione Studium Generale w Krakowie realizowało tylko częściowo dawny program. W tej uczelni doszło wprawdzie do utworzenia Wydziału Lekarskiego, ale tylko z jedną katedrą. Do roku 1525 na wydziale tym można było tylko uzyskać bakalaureat i licencjat medycyny. W celu zdobycia doktoratu z tej dziedziny trzeba było udać się na dalsze studia za granicę. Myśl, że człowiek nie jest tylko duszą, lecz także ciałem, była zgodna z nauką chrześcijańską, ale w tym czasie była szczególnie propagowana przez przedstawicieli humanizmu renesansowego. Odmienność polegała tu

21-24 Tamże, s. 248. 
na różnicy w akcentowaniu tych dziedzin. Surowy ascetyzm średniowieczny nakazywał raczej troskę o duszę, której celom miało służyć ciało. Humaniści tymczasem podkreślali harmonię zachodzącą między duszą i ciałem człowieka.

W swojej mowie inauguracyjnej Stanisław ze Skarbimierza poświęcił stosunkowo dużo miejsca naukom wyzwolonym, a to $\mathrm{z}$ tego powodu, że one najbardziej odnoszą się do człowieka, który z jednej strony jest zwierzęciem pragnącym $\mathrm{z}$ natury żyć w państwie i społeczeństwie, a $\mathrm{z}$ drugiej strony od pozostałych stworzeń ziemskich odróżnia się dzięki swoim boskim władzom i cnotom: „Nauki wyzwolone, jak wybornie stoi w księdze $O$ pocieszeniu, naprawiają serce tego, kto w nich celuje. Nauki te przydają zacności, bo ich przedmiotem jest człowiek, boskimi obdarzony władzami i cnotami, który z natury swojej jest zwierzęciem politycznem i cywilnem" 25. Ze stwierdzenia tego przebija apoteoza życia obywatelskiego i społecznego oraz godności człowieka. Pełnemu ukształtowaniu człowieka, zdaniem Stanisława ze Skarbimierza, miały służyć głównie nauki wyzwolone i filozoficzne. Spośród tych pierwszych wymienił on nie tylko gramatykę, retorykę i logikę, tworzące trivium, lecz także wchodzące w skład quadrivium takie nauki, jak geometria, arytmetyka i muzyka. Wśród tych ostatnich brak astronomii. Nie znaczy to bynajmniej, żeby w naszkicowanym przez pierwszego znanego rektora Studii Generalis Cracoviensis programie nauczania nauka ta nie miała być uwzględniona. Nie użył on wprawdzie słowa 'astronomia', ale w zamian za to wymienił meteorologię i teoryki ruchów plantearnych. Było to nie tylko dokładniejsze sprecyzowanie przedmiotu astronomii, ale i rozszerzenie jego zakresu.

Nauczanie filozofii miało tymczasem ograniczać się tylko do niektórych jej działów. Stanisław ze Skarbimierza bowiem mówił tylko o nauczaniu filozofii praktycznej, a więc monastyki, czyli etyki indywidualnej, ekonomiki i polityki:

„A teraz przystąpię z kolei do magistrów nauk wyzwolonych, którzy zakładają podwaliny nauk przez gramatykę, ozdabiają przez retorykę, prawdę od fałszu rozeznawać uczą przez logikę, rozmierzają niebo i ziemię przez geometryą, dziwne i trudne rzeczy obrachowują przez arytmetykę, zgadzają głosy przez muzykę, tajemnic niebieskich dociekają przez meteorologią, gwiazd wschód i zachód, znaków niebieskich kształty poznają, czuwają nad wpływem planet przez teorykę, naprawiają przez monastykę, podnoszą przez ekonomią, pomnażają przez politykę" ${ }^{26}$.

Tymczasem mówca nie wspominał o ogromnym dziale filozofii teoretycznej, w skład której wchodziła filozofia przyrody, matematyka i metafizyka. Pominięcie matematyki można wytłumaczyć tym, że wymieniał

25 Tamże, s. 250.

26 Tamże, s. $248 \mathrm{n}$. 
on tę naukę już przy podawaniu dyscyplin wyzwolonych. Biorąc pod uwagę fakt, że meteorologia była wówczas zaliczana i do filozofii przyrody, i do nauk astronomicznych, można ostatecznie zgodzić się z tym, iż jedną z dyscyplin filozoficzno-przyrodniczych uwzględniono, ale nie była to najważniejsza, za którą uchodziła niewątpliwie fizyka. Tymczasem zupełnie pominął on metafizykę, która w ujęciu Arystotelesa stanowiła pierwszą filozofię, a w przekonaniu filozofów klasycznego średniowiecza uchodziła za naczelną naukę wśród dyscyplin filozoficznych. Gdyby Stanisław ze Skarbimierza pominął tylko metafizykę, można by ten fakt wytłumaczyć wpływami skrajnego nominalizmu, w szczególności orientacji okhamowskiej. Nieuwzględnienie jednak prawie całego działu filozofii spekulatywnej świadczy jeszcze o czymś więcej: wykładana w Krakowie filozofia nie miała służyć kontemplacji, lecz działaniu. Tego rodzaju idee przewijały się w czternostowiecznym praktycyzmie nowej szkoły, ale jeszcze pełniejszy wyraz znalazły one u niektórych przedstawicieli humanizmu renesansowego, który $\mathrm{m}$. in. lansował tezę, że działanie jest zasadniczym powołaniem człowieka na ziemi ${ }^{27}$. Stanisław ze Skarbimierza podkreślał więc, że Wydział Umiejętności przez podnoszenie kultury i moralności człowieka spełnia zadania społeczne, przynosi zaszczyt Kościołowi i pożytek królestwu polskiemu oraz uświetnia majestat królewski:

„Ten fakultet zasługuje na cześć, uwielbienie i laski, bo przez niego pomnażają się zaszczyty Kościoła i pożytki dla królestwa polskiego; on wzbogaca ciało, duszy szlachetności przydaje it to wszystko, czem majestat królewski świetnieje; przez niego iskrzyć się będzie mądrość, przyozdobi się cała społeczność, a niecnota pójdzie na wygnanie" 28.

Wygłoszona przez Stanisława ze Skarbimierza mowa z okazji oficjalnej inauguracji odnowionego Uniwersytetu Krakowskiego zawierała więc szereg elementów humanistycznych. Była bowiem nacechowana troską o pełny rozwój człowieka. Rozwój ten miał polegać przede wszystkim na harmonijnym rozwijaniu kultury umysłowej i moralności. Tacy ludzie bowiem przyczyniają się najbardziej do utrzymania ładu społecznego, a przede wszystkim są najlepszymi budowniczymi potęgi państwa.

\section{JAGIELLOŃSKI PROGRAM NAUCZANIA FILOZOFII}

Już w roku oficjalnej inauguracji roku akademickiego w Uniwersytecie Krakowskim przystąpiono do redagowania pierwszego statutu dla całej uczelni. Statut ten niestety nie zachował się. Znany jest tylko

27 E. Garin, Filozofia odrodzenia we Wroszech, Warszawa 1969, s. 111.

28 M. Wiszniewski, jw., s. 249. 
skład komitetu redakcyjnego ${ }^{29}$. W jego skład wchodzili: doktor prawa kanonicznego Stanisław ze Skarbimierza jako rektor Uniwersytetu Krakrakowskiego; doktor teologii Jan Isner, który jako pierwszy został inkorporowany do krakowskiego Wydziału Teologii ${ }^{30}$, i być może był jego dziekanem; doktor obojga praw Mikołaj z Gorzkowa, kanonik i oficjał krakowski, pierwszy dziekan Wydziału Prawa Kanonicznego; magister nauk wyzwolonych i bakałarz-sentencjariusz teologii Jan Szczekna, który przypuszczalnie w roku 1400 był dziekanem krakowskiego Wydziału Umiejętności; dwaj magistrzy artium i bakałarze biblijni Mikołaj Pyser ze Sługocina i Bartłomiej z Jasła. Można się domyślać, że $w$ tym zaginionym statucie chodziło raczej o podstawy organizacyjne całej uczelni niż o programowe założenia nauczania uniwersyteckiego na początku panowania dynastii Jagiellonów.

$\mathrm{Na}$ podstawie wytycznych zawartych $\mathrm{w}$ przywileju fundacyjnym Władysława Jagiełły przystąpiono wnet do opracowania programów nauczania dla poszczególnych wydziałów. Pierwsza redakcja takiego programu zachowała się tylko dla Wydziału Sztuk Wyzwolonych. Statuty innych fakultetów znane są tylko z późniejszych redakcji. Stąd nie oddają one już pierwotnego ducha jagiellońskiej odnowy Studium Generale w Krakowie.

Zredagowane w latach 1404-1406 przez Stanisława ze Skarbimierza, Erazma z Nysy, Alberta z Młodzowa i Franciszka z Brzegu statuty dla Wydziału Sztuk Wyzwolonych Uniwersytetu Krakowskiego podawały ogólne podstawy organizacyjne tego fakultetu i wytyczały w ogólnych zarysach program nauczania, realizowany podczas wykładów, ćwiczeń i dysput ${ }^{31}$. Podobnie jak $\mathrm{w}$ innych ośrodkach uniwersyteckich, tak i w Krakowie nauka polegała nie na wykładzie określonych dyscyplin, lecz na bezpośrednim objaśnianiu przyjętego kanonu dzieł. Statuty tego wydziału, które były nieznacznie uzupełniane w latach 1449, 1451, 1459, 1462, 1480, 1485 i $1491^{32}$, nie zalecały wprost, co ma stanowić przedmiot wykładów i ćwiczeń. O tym możemy wnioskować tylko pośrednio. Określały one bowiem dosyć dokładnie, jakich wykładów i jak długo powinni słuchać studenci przed bakalaureatem i magisterium. Z tego zaś wynika przynajmniej, że te wykłady prowadzono. Zachowane schedy, czyli świadectwa wystawiane studentom, i tzw. Księga pilności, w której każdy z dziekanów tego fakultetu zapisywał nie tylko, co poszczególni mistrzo-

${ }^{29}$ BJ rkps 226, k. $197 \mathrm{v}$; por. Z. K o złowska-Budkowa, jw., s. 56-57 (przypis 71).

${ }_{30}$ M. M a rkow ski, Spis osób..., jw. s. 171.

${ }^{31}$ Statuta nec non Liber promotionum philosophorum ordinis in Universitate studiorum Jagellonica ab anno 1402 ad annum 1849, ed. J. M uczkowski, Cracoviae 1849.

${ }^{32}$ Tamże, s. XX, XVIII-XXXII, XL, XLII. 
wie nauk wyzwolonych wykładali, lecz także oceniał, jak wywiązywali się oni ze swoich obowiązków, potwierdzają to i wzbogacają nowymi szczegółami. Mimo że przy opracowaniu jagiellońskiego programu nauczania nauk wyzwolonych i filozoficznych wzorowano się na starszych uniwersytetach europejskich, krakowski program nauczania tych nauk różni się w niektórych szczegółach od wzorów obcych, gdyż miał służyć określonym zadaniom środowiska rodzimego.

Jak na innych wydziałach sztuk wyzwolonych, tak i w Krakowie program nauczania realizowano w dwóch etapach: pierwszy kończył się zdobyciem stopnia bakałarza nauk wyzwolonych, a drugi - uzyskaniem stopnia magistra z tej dziedziny. Studenci tych dwóch kursów byli zobowiązani do wysłuchania określonej liczby wykładów. Na pierwszym z nïch, czyli niższym, trwającym około dwóch lat, trzeba było wysłuchać jedenastu lektur, tj. drugą część Doctrinale puerorum Aleksandra z Villedieu (de Villa Dei), Poetria nova Ganifreda z Vinsauf (de Vino Salvo) lub uczęszczać na ćwiczenia z retoryki, Computus chirometralis, traktaty logiczne Piotra Hiszpana, dzieła tworzące tzw. logikę starą i nową, Fizykę i $O$ duszy Arystotelesa oraz Traktat o sferze Jana z Holywood (Ioannes de Sacro Bosco) ${ }^{33}$. Kurs niższy, jak to widać z podanych tytułów dzieł, realizował na poziomie akademickim znacznie rozszerzony program trivium. Już z samego przeglądu dzieł widać, że realizowano go nierównomiernie, gdyż największą liczbę z objaśnianych dzieł stanowiły traktaty logiczne. Program trivium był jeszcze poszerzony przez dwa podstawowe dzieła z filozofii przyrody (Fizyka i $O$ duszy Arystotelesa) i Traktat o sferze, poruszający problematykę kosmologiczną i astronomiczną, oraz przez tzw. komput, który łączono z szeroko pojętą astronomią.

$\mathrm{Na}$ kursie wyższym, przeznaczonym dla bakałarzy nauk wyzwolonych przygotowujących się do magisterium, objaśniano u nas tylko jedno dzieło logiczne; były nim Topiki Arystotelesa. Największa liczba dzieł stanowiących przedmiot wykładów przypadła tymczasem na filozofię. Były to pozostałe główne dzieła filozoficzno-przyrodnicze Arystotelesa: $O$ niebie $i$ świecie, $O$ powstaniu i ginięciu, Meteory i Krótkie traktaty przyrodnicze. Przedmiotem wykładów na tym kursie była też Metafizyka Arystotelesa. Dopiero dla magistrantów wykładano filozofię praktyczną; oczywiście podobnie jak na innych uniwersytetach europejskich, tak i w Krakowie opierano się przy tym na Etyce nikomachejskiej, Polityce i Ekonomice Arystotelesa. Na kursie wyższym krakowskiego Wydziału Sztuk Wyzwolonych podstawę do wykładów dialektyki i filozofii stanowiło więc aż 10 dzieł Arystotelesa. Na kursie magistranckim objaśniano

ss Tamże, s. XII-XIII. 
jeszcze dzieła dotyczące dyscyplin tworzących w wiekach średnich quadrivium, tj. arytmetyki, geometrii, teorii muzyki, optyki i teoryk ruchów planetarnych ${ }^{34}$. Nauki zaliczane wówczas do quadrivium, obecnie zaś poza teorią muzyki, należące do nauk ścisłych, nie likwidowały pod względem liczebności przewagi dzieł Arystotelesa.

Zredagowane w roku 1406 statuty dla krakowskiego Wydziału Nauk Wyzwolonych nie zalecały bynajmniej arystotelizmu jako głównej orientacji doktrynalnej przy nauczaniu filozofii i logiki. Niemniej o ile programowanie nauczania filozofii na tym fakultecie według dzieł Arystotelesa można sobie wytłumaczyć stosowaną praktyką na innych uczelniach uniwersyteckich, o tyle przy wyznaczeniu określonego czasu na objaśnianie poszczególnych dzieł nie kierowano się bynajmniej ani ich objętością, ani przyjętym wzorem obcym, lecz polskimi potrzebami społeczno-kulturalnymi. Potrzeby te nakazywały preferować niektóre nauki. Mogło to się odbyć bądź przez fundowanie dodatkowych katedr, bądź przez wyznaczenie większej liczby godzin na wykłady. Ponieważ młody Uniwersytet Krakowski borykał się z poważnymi trudnościami finansowymi, pierwsza możliwość nie wchodziła raczej w rachubę. Pozostała tylko druga i z tej skorzystali właśnie autorzy statutów Wydziału Umiejętności Uniwersytetu Krakowskiego.

Do najbardziej preferowanych dyscyplin na omawianym fakultecie należała filozofia przyrody. Znalazło to swój wyraz w tym, że przedmiotem wykładów były ówczesne najważniejsze dzieła z tej dziedziny i że na objaśnianie tych dzieł przeznaczono w sumie dwadzieścia siedem miesięcy czasu. W obrębie zaś filozofii przyrody za najbardziej uprzywilejowaną naukę uchodziła fizyka, będąca wtedy bardziej nauką filozoficzną niż przyrodniczą. Uznanie filozofii przyrody z fizyką na czele za naukę, którą trzeba w szczególny sposób rozwijać, ma swoje implikacje filozoficzne w czternastowiecznym terminizmie, który akstrakcyjnej metafizyce przeciwstawiał konkretyzm.

Po filozofii przyrody najbardziej uprzywilejowaną dyscypliną była logika; tej w Studium Generale w Krakowie trzeba było słuchać przynajmniej przez dwadzieścia i pół miesiąca. Logikę traktowano jako dyscyplinę przygotowawczą do studiów filozoficznych także na innych wydziałach. Podczas wykładów tego przedmiotu uczono metody myślenia naukowego. Przeznaczenie jednak tak wielkiej ilości czasu na wykłady stosunkowo krótkich dzieł logicznych posiada także swoje podstawy w czternastowiecznym terminizmie.

Trzecią z preferowanych na Facultas Artium Liberalium Uniwersy-

${ }_{84}$ Tamże, s. XIII; por. M. M a rkow ski, Methodologische Grundlagen der offiziellen Universitätsbeschlüsse und Erklärungen der Professoren an der Krakauer Universität im 15. Jahrhundert, „Studia Mediewistyczme” 17 (1977) s. 14-22. 
tetu Krakowskiego dyscyplin była filozofia praktyczna. Na jej wykłady przeznaczono w sumie piętnaście miesięcy, z czego aż dziewięć przypadło na naukę etyki. Był to wielki sukces dla tej nauki, której na początku XIII wieku jeszcze wcale nie uwzględniano w nauczaniu uniwersytec$\mathrm{kim}^{35}$. Przywiązywanie tak wielkiej wagi do filozofii praktycznej, a w szczególności do jej działu dotyczącego stosunków międzyludzkich, nastąpiło pod wpływem propagowanego $\mathrm{w}$ XV wieku, zwłaszcza przez terministów, praktycyzmu. Jednym z koryfeuszów w tym względzie był Jan Burydan. Czternastowieczny terminizm orientacji burydanowskiej sprawił więc, że na krakowskim Wydziale Umiejętności w szczególniejszy sposób zatroszczono się o rozwój filozofii przyrody z fizyką na czele, logiki z dialektyką na czele i filozofii praktycznej z etyką na czele.

Fundator, odnowiciele i organizatorzy założonego w Krakowie uniwersytetu dążyli do dostosowania jego profilu naukowego do aktualnych potrzeb kulturalnych, społecznych i państwowych. W ten sposób młoda uczelnia uniwersytecka od pierwszych chwil swego istnienia została włączona w wir skomplikowanych spraw politycznych państwa polskiego. Takie zresztą nadzieje w Uniwersytecie Krakowskim pokładał i jego fundator, król Kazimierz Wielki, i jego odnowiciele: królowa Jadwiga i król Władysław Jagiełło. Zmienione warunki historyczne wszakże sprawiły, że inne zadania stawiał tej uczelni ten pierwszy, a inne - ci ostatni. O ile Kazimierz Wielki przez wykształcenie jak największej liczby prawników, którzy by mu służyli jako znakomici doradey, dobrzy dyplomaci i wysoko kwalifikowani urzędnicy, dążył do wzmocnienia władzy monarszej i do jeszcze większego scalenia dzielnicowego państwa polskiego poprzez więzy kultury rodzimej, o tyle Władysław Jagiełło przez położenie nacisku na wykształcenie ogólne i teologiczne chciał Koronie Polskiej zapewnić dalszy wzrost i jeszcze większą trwałość, a na Litwie i Rusi wprowadzić pełną chrystianizację. W pierwszym przypadku Uniwersytet Krakowski miał więc spełniać utylitarne cele głównie wobec państwa; w drugim zaś przypadku doszły jeszcze zadania wobec Kościoła. W Kazimierzowskiej fundacji ani filozofia, ani nauki wyzwolone nie miały odegrać większego znaczenia. Zupełnie inaczej pod tym względem przedstawiała się ich rola w jagiellońskiej odnowie Studium Generale w Krakowie. Stało się tak wskutek tego, że najbliżsi doradcy królewscy,

${ }^{85}$ Por. M. de Wulf, Histoire de la philosophie mediévale, t. 2, Paris 1925, s. 154 n.; J. Rebeta, jw., s. 52. 
zarówno Jadwigi jak i Władysława Jagiełły, rekrutowali się w dosyć pokaźnej liczbie z wychowanków Uniwersytetu Praskiego. Ci zaś posiadali gruntowne wykształcenie filozoficzne. Doceniając jego walory, uwzględnili oni w szerokim stopniu filozofię przy określaniu programu nauczania odnowionej Wszechnicy Uniwersyteckiej. Posiadało to szczególnie doniosłe znaczenie dla najliczniejszego i dającego ogólne wykształcenie Wydziału Sztuk Wyzwolonych. Program tego fakultetu, zdaniem jego organizatorów, miał nie tylko odgrywać służebną funkcję wobec trzech wydziałów elitarnych, tj. teologii, prawa kanonicznego i medycyny, lecz także przyczynić się do ogólnego podniesienia kultury w całym kraju. Przywilej fundacyjny, wydany przez Władysława Jagiełłę, mówił nawet wyraźnie o podniesieniu poziomu kultury umysłowej społeczeństwa polskiego do tego stopnia, by nastąpiło zrównanie $\mathrm{z}$ innymi narodami.

Ostatni polski król z dynastii Piastów swojej idei ufundowania w Krakowie wszechnicy uniwersyteckiej nie zdołał zrealizować w całej pełni. W wyniku przeszkód spowodowanych chyba przez króla Czech i Niemiec - cesarza rzymskiego Karola IV, i przez biskupa krakowskiego Bodzantę uzyskał on tylko zgodę papieską na założenie kadłubowego uniwersytetu z wydziałami prawa, medycyny i nauk wyzwolonych. Rychła śmierć króla-fundatora sprawiła, że podwaliny rzucone pod Uniwersytet Krakowski okazały się nietrwałe.

Do powziętej przez Kazimierza Wielkiego idei założenia w stolicy państwa polskiego studium generale w pełnym ówczesnym znaczeniu tego słowa zapaliła się promieniująca ogładą kulturalną i wykształceniem Jadwiga, nosząca od 1384 roku królewską koronę Polski. Przy pomocy swego męża króla Władysława Jagiełły i najbliższych doradców zdołała u papieża Bonifacego IX uzyskać zgodę na założenie w Krakowie także Wydziału Teologii. Tym samym zaistniały pewne podstawy do otwarcia czterowydziałowego Studium Generalnego w stolicy Polski. To, co pozostało po śmierci wielkiej królowej, stworzyło w jakieś mierze podstawę materialną do egzystencji odnowionego Uniwersytetu Krakowskiego. O jej zasługach przy jagiellońskiej odnowie tej uczelni, a zwłaszcza Wydziału Teologii, pamiętali długo krakowscy teolodzy. Przy różnych okazjach, w szczególności zaś przy uzyskiwaniu stopni naukowych wspominali oni z wdzięcznością świetlaną postać zmarłej $\mathrm{w}$ kwiecie wieku królowej-odnowicielki. 


\section{DIE GRUNDLAGEN DES UNIVERSITÄTSLEHRPLANS IN DEM VON JAGIELLO NEUGEGRUNDETEN KRAKAUER STUDIUM GENERALE}

\section{Z u s a m m e $\mathrm{n}$ a s s u $\mathrm{ng}$}

Das von König Kasimir d. Gr. am 12. Mai 1364 gegründete Krakauer Studium Generale war die zweite mitteleuropäische Universität nördlich der Alpen und östlich des Rheins. Trotz der Bemühungen des polnischen Monarchen war dies lediglich eine Hochschule mit drei Fakultäten, des Rechts, der Medizin und der Freien Künste. Ihre Aufgabe war es, das Niveau der Kultur im Lande zu erhöhen, Juristen für die Verwaltungsbehörden auszubilden und ein zusätzlicher Faktor der Vereinigung des ganzen polnischen Volkes und Schutz gegen fremde Einflüsse zu sein.

Zur Neugründung des nach Tode seines Gründers verfallenen Studium Generale kam es erst, als sich die junge Königin Polens Hedwig für die Idee des großen Piasten entflammte. Am 11. Januar 1397 gab Papst Bonifatius IX durch eine an König Wladislaus Jagiello und Königin Hedwig gerichtete Bulle seine Zustimmung zur Errichtung der ersten Fakultät der Theologie auf polnischem Boden. Dieser päpstliche Erlaß bildete die rechtliche Grundlage für die Neugründung des seitdem nicht nur drei, sondern vier Fakultäten umfassenden Krakauer Studium Generale. Die große Königin Polens erlebte den Tag der feierlichen offiziellen Eröffnung der neugegründeten Krakauer Universität zwar nicht mehr, doch die von ihr dieser Hochschule vermachten Güter waren das materielle Fundament für den Unterhalt derselben in den ersten Jahren ihrer Existenz. In der jagellonischen Neugestaltung des Universitätslehrprogramms fiel die entscheidende Rolle den Fakultäten der Freien Künste und der Theologie zu. Die erste sollte durch Vermittlung reichen Wissens aus dem Gebiet der humanistischen, der exakten und besonders der philosophischen Wissenschaften Kandidaten für das Studium an den drei höheren Fakultäten vorbereiten und dazu beitragen, daß in Polen die Anzahl von Menschen mit Hochschulbildung zunahm. Die zweite Fakultät dagegen sollte Theologen ausbilden, die im Lande fehlten und die auch entsprechend vorbereitet sein sollten für die Missionsaufgaben unter der zum Teil schismatischen, zum Teil noch heidnischen Bevölkerung Litauens und Rutheniens. 